\section{総 説}

Review

\title{
Commentary of Hard Tissue Biomaterials
}

\author{
by Masayuki OKAZAKI ${ }^{\text {a }}$
}

a. Professor Emeritus, Hiroshima University

(Corresponding author, E-mail: okazakitty13@ybb.ne.jp, FAX: 075-921-0628)

For therapeutic use of hard tissue biomaterials, a number of biomaterials have been investigated eagerly. Especially titanium and sintered hydroxyapatite have been used from the viewpoint of biocompatibility. Last century sintered ceramics such as calcium phosphates were main hard tissue biomaterials from the view point of mechanical strength. However, they are fundamentally less biodegradable and not easy to process. Recently, tissue engineering has been developed. Various kinds of scaffold biomaterials have often been used in medical and dental fields. The concept of biomaterials has appeared to shift to biodegradable scaffold biomaterials.

On the other hand, inorganic materials of human hard tissues such as bone and teeth are composed with hydroxyapatite. Tooth enamel is well-crystallized, contrary to poorly-crystallized dentine and bone. Physicochemical properties of apatites are affected dramatically by the substitution of trace elements. Especially, biological apatites constituting bone and teeth contain several $\mathrm{wt}_{\%} \mathrm{of} \mathrm{CO}_{3}{ }^{2-}$ ions, which are related to the crystallinity and solubility. Recently, scaffold biomaterials are expected with a shape-maintaining property in addition to large pores and high porosity, in which cells can easily invade. To develop a new biodegradable scaffold biomaterial, bone-like carbonate apatites $\left(\mathrm{CO}_{3} \mathrm{Ap}\right)$ were synthesized and $\mathrm{CO}_{3} \mathrm{Ap}$-collagen scaffolds were created. This scaffold biomaterial is useful itself for the region with bone regeneration ability. When these sponge-frame complexes with rh-BMP2 were implanted beneath the periosteum cranii of rats, sufficient new bone was created after 4 wks' implantation. Furthermore, when the $\mathrm{CO}_{3}$ Ap-collagen sponge containing SVVYGLR peptide was implanted as a graft into a tissue defect created in rat tibia, the migration of numerous vascular endothelial cells as well as prominent angiogenesis inside the graft could be detected after 1 week. Thus, the modification of higher function such as cytokine and angiogenesis factors is effective for low regeneration region as tissue engineering biomaterials.

KEY WORDS: Hard Tissues, Biomaterials, Apatites, Collagen, Composites, Regeneration

\section{1. 生体材料とは?}

1960 年代後半の宇宙競争と冷戦の最中, 世界では地球そのも のを, 我々の生活そのものを見つめなおす必要があるとの機運が 高まってきていた。そのような状況から, 将来の学問ビジョン として浮かび上がってきたのが生命科学 Life science である。そ の中で, 大きく発展していくことになる分野が医用工学 Medical engineering と細胞工学 Bio-technology であり, 両者の学問を支え るため縁の下の力持ちのような存在として登場してきたのが生体 材料 (バイオマテリアル Biomaterials) である。

生体材料の定義は, 1974 年, 第 6 回国際バイオマテリアル学 会において,「生体材料とは, 生体組織の中に移植されたり, あ るいは接触した場合に, 組織学的, 薬理学的に不活性な物質の こと A biomaterial is a systemically, pharmacologically inert substance

*2012 年 5 月 23 日受付 2012 年 7 月 4 日受理

1. 広島大学名誉教授

[ 著者連絡先 ] FAX: 075-921-0628

E-mail: okazakitty13@ybb.ne.jp

キーワード : 硬組織, 生体材料, アパタイト, コラーゲン, 複合体, 再生 designed for implantation within or in corporation with living systems との表現 ${ }^{1 ）}$ が基準となっているが, 最近の組織工学 Tissue eingineering の登場によりその再定義も必要になりつつある。と りわけ，従来は半永久的な使用を中心に考えられていた生体材料 も, 代謝性を重視した考えに変わりつつある。特に, 細胞の増殖 の足場という発想で登場してきたのが “スカフォールド scaffold” という概念であり, ES 細胞 (胚性幹細胞 : Embryonic Stem cells) や iPS 細胞 (人工多能性幹細胞 : induced Pluripotent Stem cells) と いった再生医療の花形の研究においても生体材料は裏方として欠 かせない。

生体材料を歴史的に眺めてみると，人工材料を使った治療とし ては医科領域よりもむしろ歯科領域における歴史が古く, すでに エジプトで $3000 \mathrm{BC}$ 頃には歯科補綴が行われていたとの記録が残 されている。恐らく金を使った歯の修復治療が行われていたもの と推測される。700BCになると, エトルスカン (イタリアのエス トニア地方, トスカーナ地方の古名）において, 天然歯のブリッ ジが行われている。まさに生体材料の曙とも言うべき補綴物が幾 つか発見されている (Fig. 1) ${ }^{2}$ )。恐らく歯周病 (歯槽膿漏)によっ て抜歯を余儀なくされたのであろう。ただ，このような再植術に 


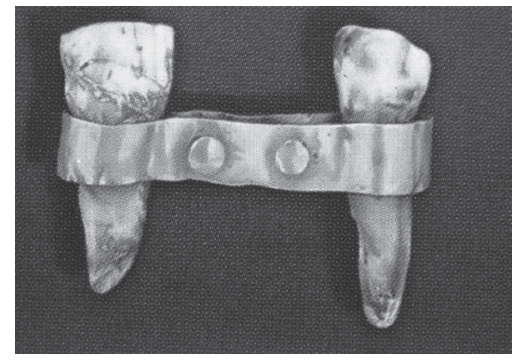

Fig.1 Ancient Etruscan gold implant bridge.

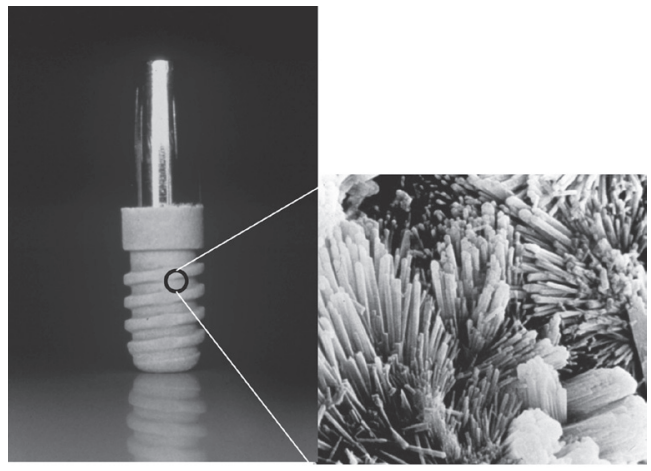

Fig.2 Artificial tooth, $\mathrm{AQB}^{\circledR}$ Implant System (by courtesy of Advance Co. Ltd).

より抜け落ちた歯が再び機能していたか否かは定かではない。日 本における生体材料として注目す心゙きは「木床義歯」である。日 本には昔から入れ歯師という専門職能人がいて歯科治療に貢献し ていた。人工歯は象牙や蝋石で, 床は黄楊の木でつくられ, 口 腔粘膜面への吸着は良好であったと言われている。整形外科領域 においては，すでに 1725 年にこの領域のバイブルとも言うべき “Orthopaedic”が登場している。1 18 世紀後半には仏人陶工が人工 歯を作成し，この技術が米国へと渡った。日本では，1922 年に 松風陶歯 (現在の (株) 松風) が当時としては大規模な工場を創 業している。

金属生体材料が本格的に医療の分野で使われ出したのは20世 紀に入ってからであり，当初はなんと言っても，ステンレス鋼 SUS316L (steel-special use stainless) である。ステンレス鋼とは普 通の炭素鋼に比較して, 特に耐食性に優れた特殊鋼の総称であ り，18-8 ステンレス鋼 (Cr18\%-Ni8\%) が有名である。1938 年に は, Strock (米国)による Vitalium ${ }^{\circledR}$ (Co-Cr-Mo 合金) が登場し, 今日でも広く人工股関節をはじめとする各種生体材料として利用 されている。また, 生体親和性金属材料として知られる $\mathrm{Ti}$ は最 もポピュラーであり，1967 年には Linkow (米国) が人工歯根と して用い, それ以降 Bränemark らにより幾多の改良がなされ今日 に至っている。さらに 1962 年 Buehlerによって, 形状記憶合金 shape memory alloy として開発された Nitinol ${ }^{\circledR}(\mathrm{Ni}-50 \mathrm{at} \% \mathrm{Ti})$ が超弾 性効果も有することから医療用にも応用されてきた。

セラミック生体材料では, 1960 年代にアルミナ $\mathrm{Al}_{2} \mathrm{O}_{3}$ が注目 を集め, 人工骨や人工歯根として使われた。しかしながら, 生体 親和性良好なリン酸カルシウム系セラミックスの登場により, 次 第に影を潜めるようになった。当初登場したのがバイオグラス Bioglas $\left(\mathrm{CaO}-\mathrm{P}_{2} \mathrm{O}_{5}-\mathrm{SiO}_{2}\right)$ であり, 生体親和性は良好であったが, 脆かったため実際には余り使われなかった。その後, 1970 年代 〜 1980 年代には, 数多くの焼結アパタイトが登場した。ブロッ クタイプから顆粒状タイプまで, さまざまな人工骨が生み出され た。しかしながら，これらの焼結アパタイトもやがて代謝性に乏
Table 1 Calcium Phosphates

\begin{tabular}{l|l|l}
\hline 略号 & \multicolumn{1}{|c}{ 名称 } & \multicolumn{1}{c}{ 化学式 } \\
\hline $\mathrm{HAp}$ & ハイドロキシアパタイト & $\mathrm{Ca}_{10}\left(\mathrm{PO}_{4}\right)_{6}(\mathrm{OH})_{2}$ \\
TCP & 第三リン酸カルシウム & $\mathrm{Ca}_{3}\left(\mathrm{PO}_{4}\right)_{2}$ \\
DCPD & 第二リン酸カルシウム二水塩 & $\mathrm{CaHPO}_{4} \cdot 2 \mathrm{H}_{2} \mathrm{O}$ \\
$\mathrm{OCP}$ & オクタカルシウムフォスフェート & $\mathrm{Ca}_{8} \mathrm{H}_{2}\left(\mathrm{PO}_{4}\right)_{6} \cdot 5 \mathrm{H}_{2} \mathrm{O}$ \\
$4 \mathrm{CP}$ & テトラカルシウムフォスフェート & $\mathrm{Ca}_{4} \mathrm{O}\left(\mathrm{PO}_{4}\right)_{2}$ \\
\hline
\end{tabular}

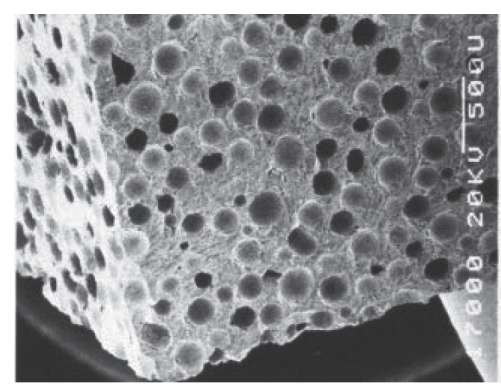

Fig.3 Porous artificial bone, BoneCeram (by courtesy of Sumitomo Cement Co. Ltd)

しいことから使用が見直されることになる。それに代わり，多 くの代謝性リン酸カルシウムが登場してくる。アパタイトや $\alpha$ TCP, $\beta$-TCP, DCPD, OCP, 4CP (Table 1) ${ }^{2)}$ と言った素材が単独で, あるいは Ti のような金属材料表面にコーティングされることに より，骨との馴染みを良好にした多くの生体材料が開発された (Fig. 2) ${ }^{2)}$ 。一方, これら代謝性アパタイトと有機質コラーゲン, キトサン, ポリ乳酸等との複合体が試作された。その後, 組織工 学の登場により, これらの材料は骨芽細胞の侵入を容易にするた めポーラスに改良された (Fig. 3) ${ }^{3)}$ 。

高分子材料の歴史は, せいぜい百数十年といったところであろ うか。ところが，これほど生活に密着している材料は他に少ない かも知れない。高分子化学は戦後 (第二次大戦後), 日本の先導 的研究で発展してきた感がある。高分子は, 結晶性の度合いから 分類すると, 繊維, プラスチック, ゴムに分類される。合成高分 子は, 石油原料に負うところが多く, 日本の高度成長を支えてき た原動力でもある。なかでも, エチレン $\mathrm{CH}_{2}=\mathrm{CH}_{2}$ は, その根幹 をな寸代表的な原料モノマーである。ここから，数知れない多く の高分子材料がつくられてきた。ポリエチレン PEそれ自体が, 日常生活に溶け込んでいる。また，人工股関節のソケットのよう に高密度ポリエチレン HDPE は医用材料として用いられている。 ポリメチルメタクリレートPMMA は, 有機ガラス Plexiglas ${ }^{\circledR}$ と して 1930 年代にドイツで開発され, 歯科用レジン (プラスチッ ク）や，ハードコンタクトレンズ用材料として長く使われ続けて いる。この PMMA は, もともと軍事用戦闘機のフロントグラス用 に開発されたと言うから皮肉である。一方, 20 世紀後半, いち早 く医療用として幅広く用いられるようになったのがシリコーンであ り, 用途によって数多くの種類のものが存在する。高分子生体材料 としては, 人工血管から人工皮膚, 人工耳介, 人工乳房といった 人工臓器や軟組織代替材料として現在の医療に貢献している ${ }^{4)}$ 。

生体を構成する天然素材を生体由来材料 biological materials と して区別する場合もあるが，一般には天然材料と人工材料とを識 別することが困難な場合もあり, 両者を広く包含した用語として 生体材料という表現を用いるのが通常である。ここでは特に, ア パタイトを中心に歯や骨のような硬組織に関連した天然および人 工の生体材料について解説することにする。

\section{2. 歯と骨の組織学的性質}

歯は骨と違い永久歯が生えそろってしまうと, 幾ら虫歯や歯周 


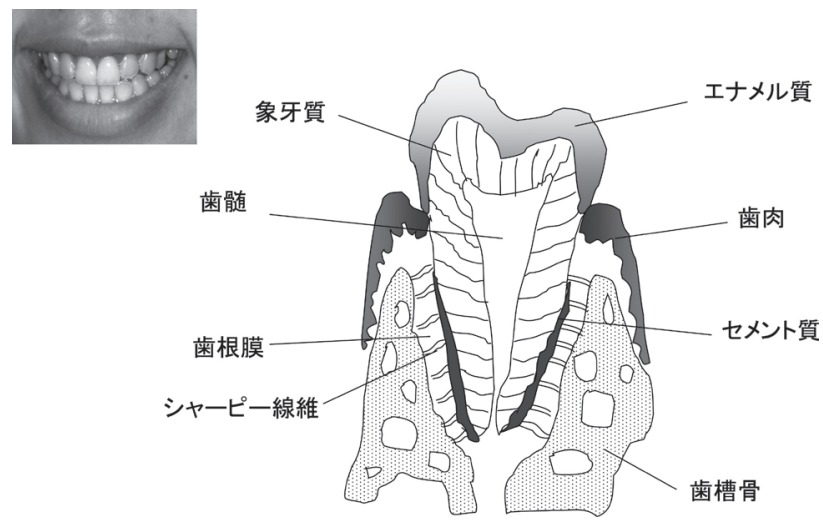

Fig.4 Structure of tooth.

病に罹っても健全な歯には戻らず，歯が抜けると二度と生えてこ ない。乳歯は 1 回永久歯に生え替わるので, 人間の歯は二生歯と 呼ばれている。それに対し, 魚の歯はどんどん入れ替わるので多 生歯と呼ばれている。乳歯は生後 6 个月から幼児期に渡って合計 20 本生え, 6 歳頃から順次脱落して永久歯に置き換わり, 最終的 には大臼歯が $8 \sim 12$ 本加わって $28 \sim 32$ 本となる。歯は外形的 に歯冠と歯根に分けることができ, 歯冠はエナメル質で覆われ大 部分が口腔に露出している。歯根はセメント質に包まれ顎骨の中 に埋まっており, 歯根の数は切歯と犬歯では 1 本, 小臼歯と大臼 歯では単根, 2 根, 多根 (3 本以上) となっている (Fig. 4)。

エナメル質は非常に硬く, 咀嚼時の咬合力に耐え, 内側の象牙 質や歯髄を守る甲羅のような役割を演じている。エナメル質では 95\%以上がアパタイトから成り, 残りは水と非コラーゲン性のタ ンパク質である ${ }^{5,6)}$ 。それに対し, 象牙質は約 $70 \%$ のアパタイ トと $30 \%$ のコラーゲン (主としてタイプIコラーゲン) から成る。 象牙質はエナメル質よりしなやかで, エナメル質との境目から直 径数ミクロンの象牙細管と呼ばれる細長い細管が縦方向に内部 に向かって何本も伸びている。この象牙細管は, やがて歯髄腔一 と到達する。歯髄は, 歯髄腔を満たす軟組織で, 細胞, 線維, 基 質，血管並びに神経で構成されており，有機質が約 $25 \%$, 水分 が約 75\% から成り根尖部を除いて, 周囲は象牙質に囲まれてい る。歯髄は, 象牙質に栄養を与えたり, 歯の知覚を司り, 刺激に 対する防御や修復の機能を持っている。歯根象牙質の表層は, 薄 いセメント質で覆われ骨によく似た結晶性を有するが，骨と異な り血管がなく再生能力はほとんどない。このセメント質には歯を 歯槽骨に結び付けるシャーピー線維と呼ばれる強い結合組織が歯 根膜を貫いて内部まで伸び歯をしっかりと固定させている。従っ て, 将来的に人工歯根の製作に当たっては, このような生体の高 機能性も考慮する必要があろう。

骨は, 常に代謝回転 (リモデリング) を繰り返しながら日々 新鮮な状態を維持している。この骨組織は, 生体力学的に見て, 我々の身体を重力下で支える重要な役割を演じている。一方, 各 種ミネラルの貯蔵庫として生命維持に欠かすことのできない役割 も担っている。骨は，歯と同様にアパタイトと有機コラーゲンか ら成っている。組織学的には Fig. 5 に示されるような緻密骨と海 綿骨に分類される7)。これも複合構造を成し, 力学的に見ても 最小の質量で最大の応力に耐えられるように設計されている。骨 は生きた細胞からできているので血管がよく分布し, 緻密骨は骨 単位あるいはハーバス系と呼ばれる血管を中心に，それを取り巻 く骨集合体の円柱より構成されている。骨の形成には骨芽細胞 osteoblast が関与し, 骨芽細胞はやがて骨細胞 osteon となる。一方, 再吸収には多核細胞である破骨細胞 osteoclast が関与し, 食作用

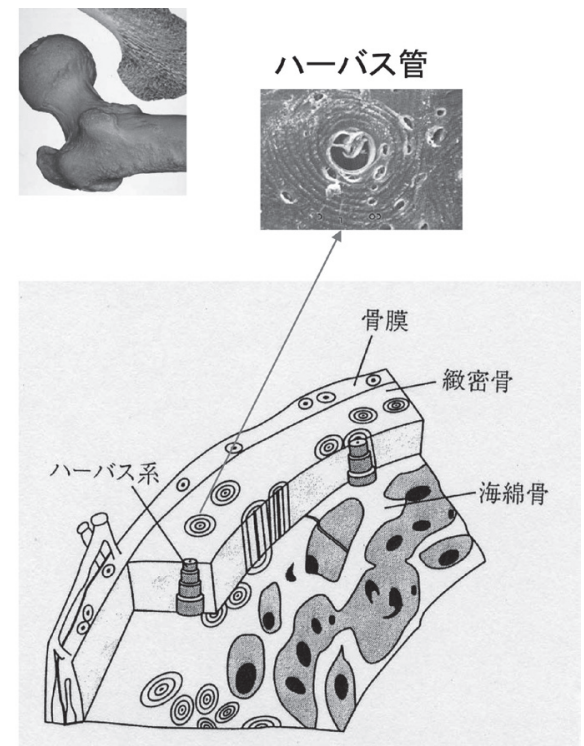

Fig.5 Structure of bone.

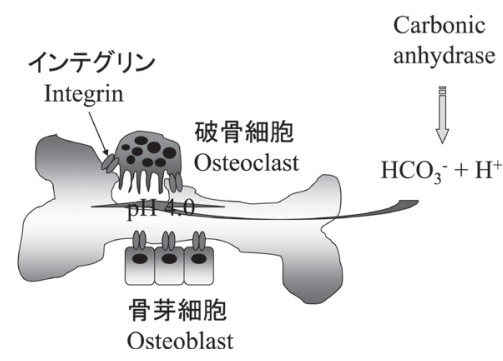

Fig.6 Bone metabolism.

により骨を取り込む。

ミクロ的には，骨の $60 \sim 70 \%$ を占める無機質はアパタイト から成るが, 実際には $\mathrm{Ca}^{2+}, \mathrm{PO}_{4}{ }^{3-}, \mathrm{OH}^{-}$以外に, 微量ではあるが $\mathrm{Mg}^{2+}, \mathrm{Fe}^{2+}, \mathrm{CO}_{3}{ }^{2-}, \mathrm{HPO}_{4}{ }^{2-}, \mathrm{F}^{-}$等といった多種類のイオンを含む。

この骨アパタイトは, 基質小胞と呼ばれるおよそ $500 \mathrm{~nm}$ の顆 粒状細胞分泌物の膜内で核形成を起こし, 徐々に結晶成長を続け ながら, ついには膜を突き破り, やがてその周辺にコラーゲン線 維がまとわりつき, 骨の初期合成が起こるとの説が有力である。 その際, Ca-ATP, Mg-ATP, アルカリフォスフォターゼ等が重要な 役割を演じていると考えられている。歯と異なる点は, 日々代謝 され生まれ変わっているという点である。骨は，骨芽細胞がつく り破骨細胞が壊している ${ }^{8)}$ 。ただ，誤解されや寸いのは，まる で破骨細胞が骨片を食ってしまうようなイメージでとらえられて いるが，実際には $\mathrm{H}^{+}$イオンが放出されアパタイト結晶が溶かさ れているのである。破骨細胞によって封鎖された局所領域では, $\mathrm{pH}$ が 4.0 近くになることが報告されている。まさに, 歯のう蝕 (虫 歯) 現象と同じことである (Fig. 6)。

骨は, ミネラル (無機質) の貯蔵庫であり, 身体無機質の恒常 性維持に貢献している。このうち, 成人の身体は約 $1,100 \mathrm{~g}$ の $\mathrm{Ca}$ を含み， 1 日に約 $1 \mathrm{~g}$ 摂取することにより，そのバランスを保っ ている。とりわけ人体の $99 \%$ の $\mathrm{Ca}$ は骨組織に含まれている。 Fig. 7 は, 成人のカルシウム代謝を表しているが, 1,000g が骨中 に安定に存在し, 交換可能な $\mathrm{Ca}$ は, わずか $4 \mathrm{~g}$ である。残りの 約 $1 \%$ が体液中や骨以外の組織に存在することになる。血漿中に は約 $250 \mathrm{mg}$ の Ca が存在することになる ${ }^{7)}$ 。

骨疾患としては，全体的な二次的代謝失調による疾患がある。 骨硬化症は, 転移腫瘍, 鉛中毒, 上皮小体機能低下症の患者に 


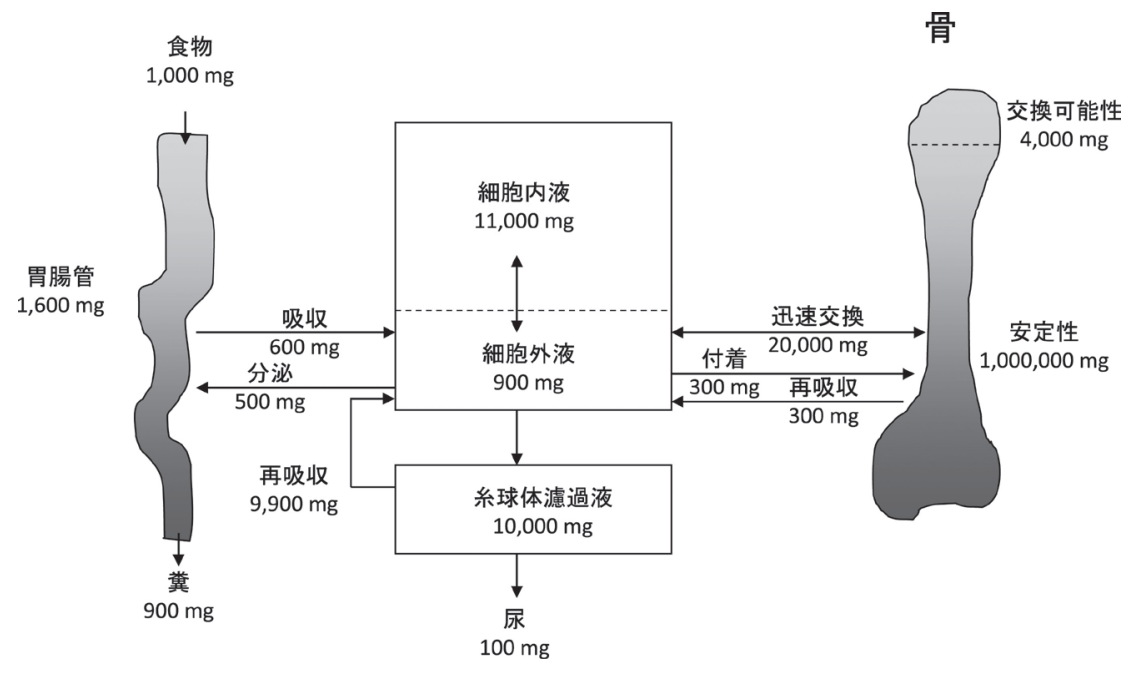

Fig.7 Calcium metabolism of adult per a day.

起こり，骨への Ca 沈着が亢進する。フッ素 F が骨に多く取り込 まれることによっても起こり，Mg 摂取が有効とされている。骨 軟化症は, くる病などに代表される疾患で, 単位骨母質当たり 無機質付着量が不十分となる。骨粗鬆症 (オステオポローシス : osteoporosis) は，最近注目されている骨吸収方進あるいは骨形成 低下の際に一般に見られる異常で, 無機質と骨母質との比が正常 でありながら骨実質が減少するものである。すなわち，全体的に 無機アパタイトも有機コラーゲンも同時に減少し, 骨が極度の多 孔質になってしまう疾患で, 特に中年期閉経後の女性に多く認め られ，ホルモンバランスと関係があると考えられている。

\section{3. アパタイトの化学的性質}

それでは，歯や骨をつくるアパタイトとはどのような物質なの であろうか。アパタイトは, リン酸カルシウムの一種で, 多く の兄弟を持っている $\left(\right.$ Table 1) ${ }^{2)}$ 。一般式で $\mathrm{A}_{10}\left(\mathrm{BO}_{4}\right){ }_{6} \mathrm{C}_{2}(\mathrm{O}$ : 酸 素）のように表され，各 $\mathrm{A}, \mathrm{B}, \mathrm{C}$ の位置には多くの原子 (イオン) が置換し得る。従って, 数多くの異なるアパタイトが存在する。 その中で, C の位置に OH イオンが置換したものが歯や骨をつく るハイドロキシアパタイトである。理論的なハイドロキシアパタ イト $\mathrm{Ca}_{10}\left(\mathrm{PO}_{4}\right)_{6}(\mathrm{OH})_{2}$ は, 六方晶系のイオン結晶で, $1 / 3$ が結 晶ユニットになっている (Fig. 8) ${ }^{2)}$ 。八イドロキシアパタイトの 結晶解析 (Fig. 9) ${ }^{9,10)}$ が確立したのは 1960 年代になってからで あり, かの有名な DNAの Watson-Crick モデルの発表に遅れるこ と 10 年である。なぜ, このように一見それほど複雑とは思えな い無機結晶の構造解析が遅れたかと言うと, ひとつにはアパタイ トの多様性に起因する。元来アパタイトは, その名の示すごとく (ギリシア語の惑わ寸の意, ペテン師とも呼ばれることがある ),

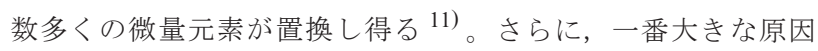
は, OH-イオンが安定位置から $0.03 \mathrm{~nm}$ ずれていたからである ${ }^{9)}$ (Fig. 10)。X線回折のみならず中性子線回折 ${ }^{10)}$ をも駆使して, ようやく構造決定がなされた。それに対し, フルオロアパタイト $\mathrm{Ca}_{10}\left(\mathrm{PO}_{4}\right){ }_{6} \mathrm{~F}_{2}$ の構造決定はすでに 1930 年代になされている ${ }^{12)}$ 。 なぜなら，F-イオンは結晶内の安定位置に丁度収まっていたか らである。

実際の生体アパタイトは, この $\mathrm{Ca}^{2+}, \mathrm{PO}_{4}{ }^{3-}, \mathrm{OH}^{-}$の位置に微量 の元素が種々置換し, さらに複雑な構造になっている。X線回折 では，エナメル質は結晶性がきわめて高く，象牙質や骨では結晶 性が低いことがわかる (Fig. 11)。従って, エナメル質の結晶サ
イズは大きく，格子不整も少ないため溶けにくいが，象牙質や骨 は結晶サイズも小さく久陷も多いため溶けや寸い。もちろん，八

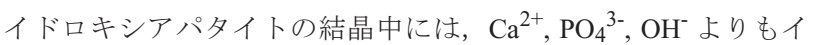
オン半径の大きな元素も置換し得るが, Fig. 12 に示すごとく殆 どが，それらよりイオン半径の小さい微量元素が生体アパタイト に含まれているようである。例えば, 微量元素としてのフッ素イ オン $\mathrm{F}^{-}$は, う蝕 (虫歯) 予防・抑制効果のあることで, よく知ら れているが, 生体アパタイトが数\%の炭酸イオン $\mathrm{CO}_{3}{ }^{2-}$ を含む“炭 酸アパタイト”からなることの詳細については意外に知られてい ない ${ }^{13)}$ 。生体アパタイトが炭酸アパタイトとも呼ばれる所以で ある。炭酸イオンがアパタイトの結晶内に置換すると, 著しく結 晶性が低下し, 結晶サイズも小さくなり, それに伴い溶解性が高 まる。このことが, 歯質エナメル質のう蝕感受性とも関係があり, 一方骨の代謝性と密接な関係を有していると考えられる。従って, 代謝性の硬組織生体材料の研究開発に当たっては, この点を十分 考慮することが大切である。

\section{4. アパタイト・コラーゲン複合体}

硬組織生体材料の発展により体内での耐久性が飛躍的に増して きたが，その反面従来の非代謝性生体材料を体内で長期間使用し ていると破損, 摩耗, 脱離, 慢性炎症等の深刻な問題が発生し, 半永久的に使用寸ることの困難さがクローズアップされてきた。 このようなことから近年の傾向として代謝性生体材料の概念が注 目されるようになってきた。我々も, 以前から骨の性状に類似し たより生体に馴染むバイオミメティック生体材料の開発研究を進 めてきた。

ここでは筆者らの炭酸アパタイト合成とその生体材料への応用 研究について少し紹介寸ることにしよう。生体アパタイトと比 較検討してみると, 生体内でのアパタイトが $37^{\circ} \mathrm{C} て ゙$ 起こるのに 対し, 骨様アパタイトを得るには残念ながら人為的合成系では, もう少し高い $60^{\circ} \mathrm{C}$ 程度の合成温度が必要であることがわかった。 $60^{\circ} \mathrm{C}$ で炭酸供給濃度を種々変えて合成すると, 結晶性の異なる炭 酸アパタイトが得られる ${ }^{14,15)}$ 。ここで興味深いことに, 炭酸含 有量が骨に近い值 $(4 \sim 6 \mathrm{wt} \%)^{15)}$ では, 結晶性が骨に類似してく る。溶解性は, おのずと結晶性や化学組成と相関する。我々のバ イオミメティックアパタイトのコンセプトは, 骨芽細胞や破骨細 胞も骨の性状や周辺細胞外液環境に馴染んでいるとの推論に基づ く。となると, 結晶性や化学組成, 溶解性が骨に類似している方 

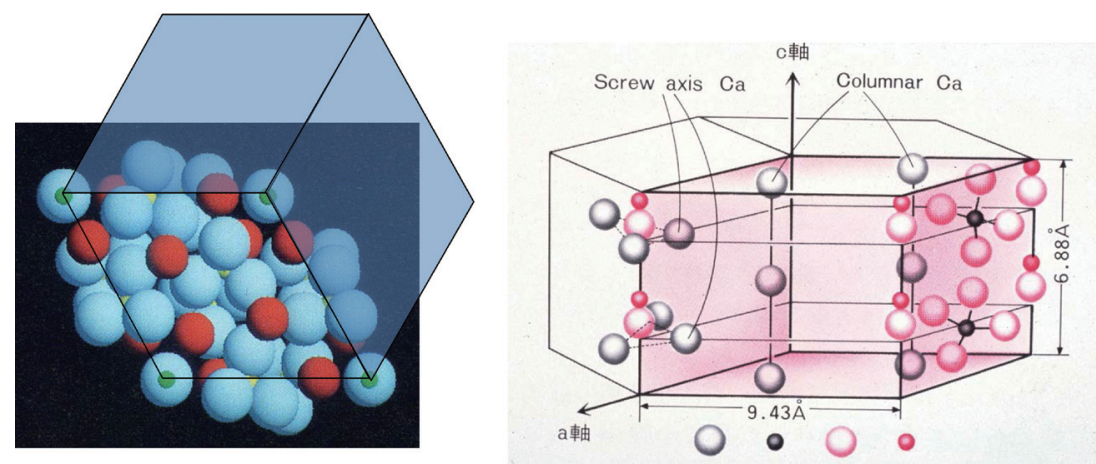

$\begin{array}{llll}\mathrm{Ca} & \mathrm{P} & \mathrm{O} & \mathrm{H}\end{array}$

Fig.8 Stereo-structure model of hydroxyapatite

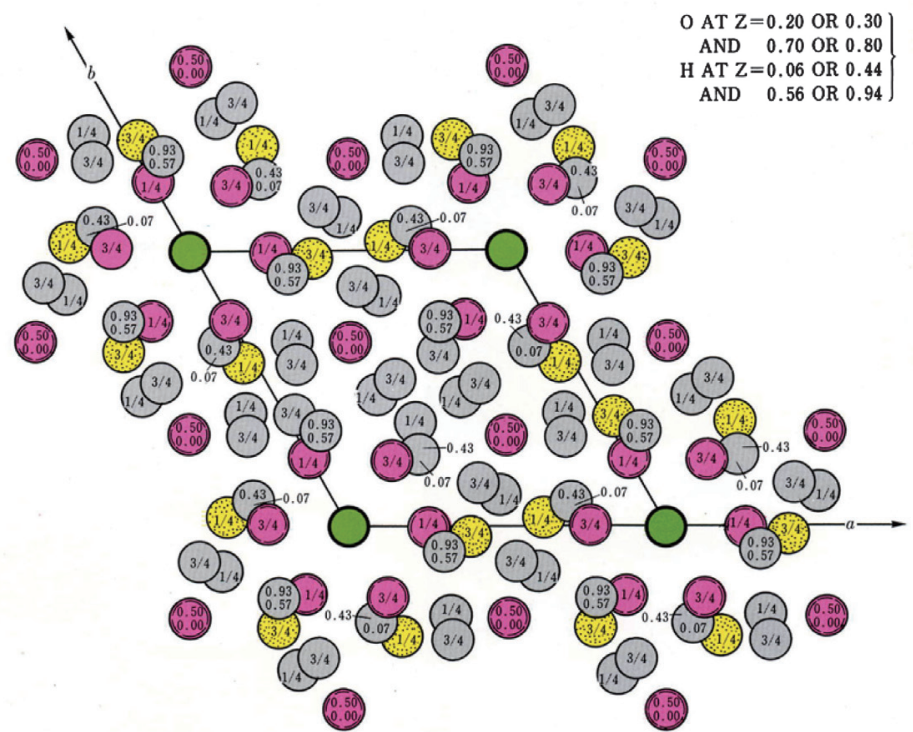

Fig.9 Crystal analysis data of hydroxyapatite with space configuration of each atom.

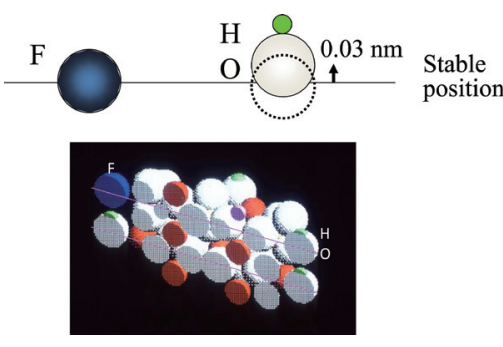

Fig.10 Shift of $\mathrm{OH}^{-}$ion from stable position in hydroxyapatite crystal.
Cations

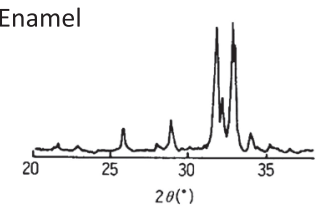

Dentine

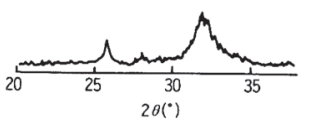

Bone

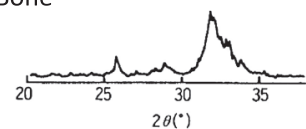

Fig.11 X-ray diffraction patterns of human tooth enamel, dentine and bone.

が好ましい。これを骨様アパタイトと定義づけた。いわゆるバイ オミメティック炭酸アパタイトである。

そこで，この概念に基づき，骨様アパタイトを選択し，抗原抗 体反応を可及的に除去した牛皮由来のアテロコラーゲンとの複合 体を作成した ${ }^{16,17)}$ 。動物実験では, 生体親和性は良好で UV 照 射による不溶化により溶液中でも一定期間形態を保持し得た。ま
(0)

(0)

(Ca)

P.

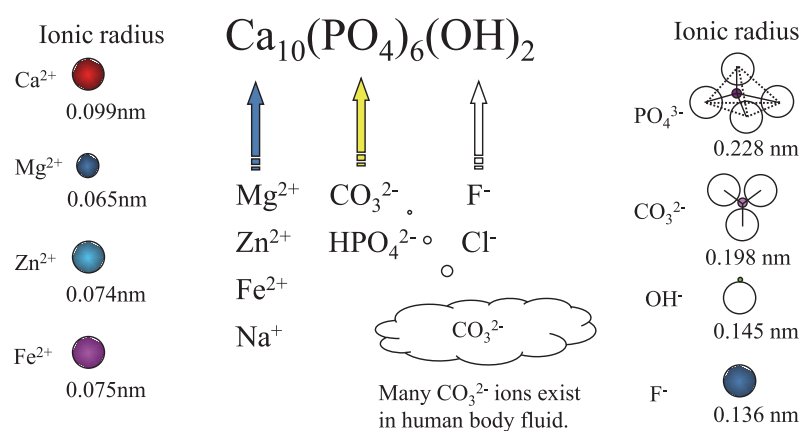

Fig.12 Substitution of trace elements into hydroxyapatite crystal.
た，細胞の侵入を容易にするため凍結乾燥によりスポンジスカ フォールド (Fig. 13) を作成したところ ${ }^{18)}$ ，骨と類似した $70 \mathrm{wt} \%$ 炭酸アパタイト・コラーゲン組成では, コラーゲン単体と殆ど変 わらない程度の空隙率を保持し (Fig. 14), 骨芽細胞様細胞のス ポンジ内部への侵入も認められ, ALPase, Osteopontinのような細 胞活性も認められた ${ }^{19)}$ 。さらに, 各種炭酸含有量の骨形成能一 の影響を検討したところ，炭酸含有量が骨に類似した炭酸アパタ イト $(4.8 \mathrm{wt} \%)$ ・コラーゲン複合体で, 高い骨形成能を示すことが 


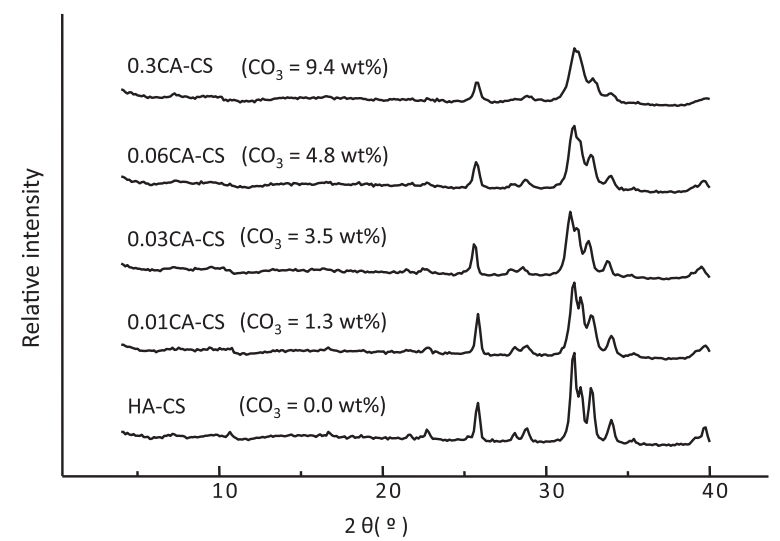

Fig.13 X-ray diffraction patterns of $\mathrm{CO}_{3}$ apatite-collagen sponges. HA-CS: hydroxyapatite-collagen sponge

CA-CS: $\mathrm{CO}_{3}$ apatite-collagen sponge (number: $\mathrm{CO}_{3} / \mathrm{P}$ supply molar ratio during synthesis)

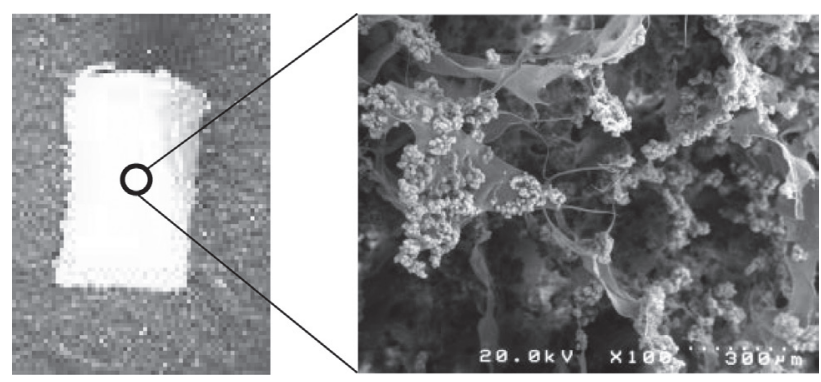

Fig.14 SEM photo of $\mathrm{CO}_{3}$ apatite-collagen sponge.

確認できた $\left.{ }^{15}\right)$ (Fig. 15)。また，家鬼を用いた長期間 (24 週 )の 埋入実験ではハイドロキシアパタイトおよび低含有量の炭酸アパ タイトはX線透過像で識別される残像が認められたが，骨様炭酸 アパタイトでは, 識別できないほどに良好な骨再生が確認できた。 この炭酸アパタイト・コラーゲン複合体は, 幅広く小さな骨欠損 部や歯周疾患, 義歯安定保持, インプラント時の骨再建等への適 用が可能であるが, 高齢者や再生能力の衰えている部位には, さ らなる骨形成促進を図るため複合体に化学的な高機能性を導入す る必要があると考えられた (Fig. 16)。そこで，まず細胞接着促 進因子としての $\mathrm{Mg}^{2+}$ イオンを置換した傾斜機能性 $\mathrm{Mg}$ 含有炭酸 アパタイトを合成して複合体を作成し動物実験を行ったところ $\mathrm{Mg}^{2+}$ イオンの骨形成促進効果が認められ (Fig. 17) ${ }^{20)}$, 骨増殖因 子として有名な BMP (Bone Morphogenic Protein) を複合体に添加 したところ旺盛な骨形成が確認できた (Fig. 18) ${ }^{21)}$ 。さらに，血 管新生因子をコラーゲンに化学修飾した際には, 埋入 1 週間後で 血管の新生が確認できた (Fig. 19) ${ }^{22)}$ 。

\section{5. 硬組織再生の課題}

実際の生体組織はきわめて精巧で, 巧みにレギュレートされて いる。理想的には, 生体組織そのもので置き換えるのが好ましい のであるが, 再生医療は, まだ始まったばかりである。現在のと ころ生体親和性 biocompatible 良好な人工材料を使用せざるを得 ない。そうなると, いかに生体と“馴染み” のある材料, “から だに優しい”材料を開発するかということになる。それには，生 体反応や構造を十分理解し応用することが大切である。

1960 年代後半に登場した細胞工学の手法は, 20 世紀末に登場 してきた組織工学に受け継がれ, 再生医療の一翼を担い急速な進 歩を遂げている。よく言われるように, 組織工学には細胞 cell,

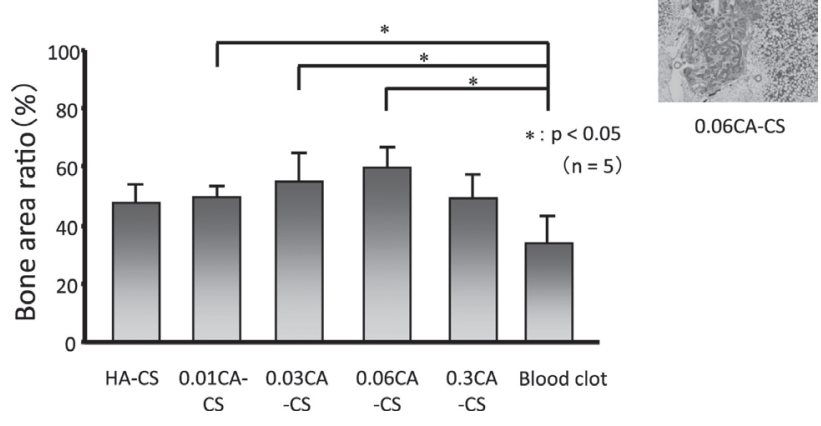

Fig.15 Bone regeneration ability of $\mathrm{CO}_{3}$ apatite-collagen sponges after 3 wk-implantation into rabbit tumor.

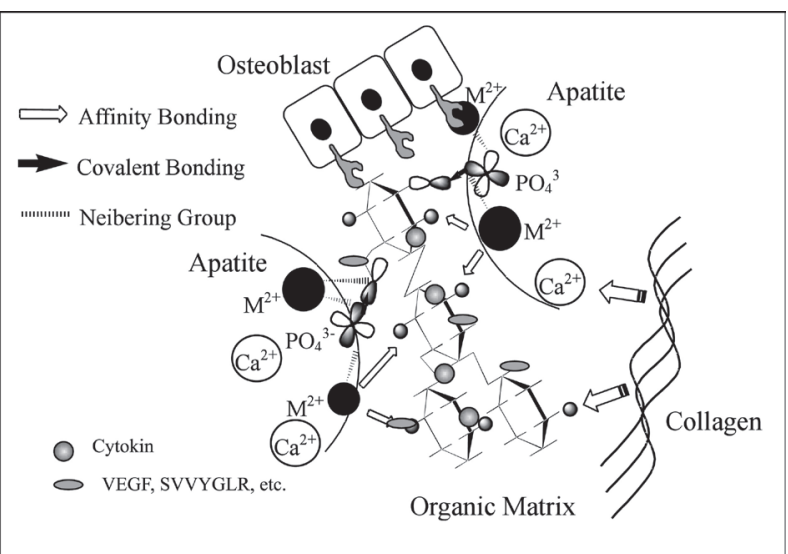

Fig.16 Chemical modification to $\mathrm{CO}_{3}$ apatite-collagen composite.
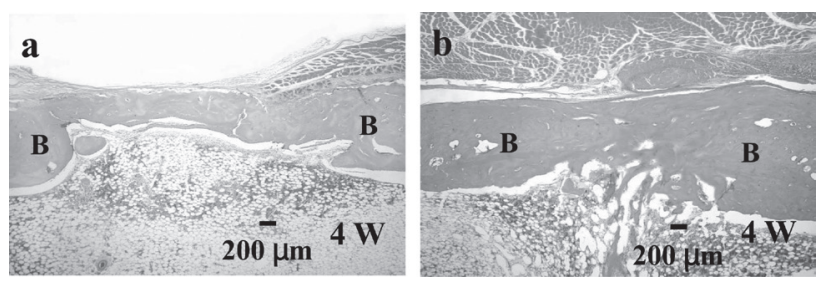

Fig.17 Hematoxylin-eosin (H-E) staining of $\mathrm{CO}_{3}$ apatite-collagen composite. A: control, b: Functionally graded $\mathrm{Mg}-\mathrm{CO}_{3}$ apatite-collagen composite, B: rabbit bone

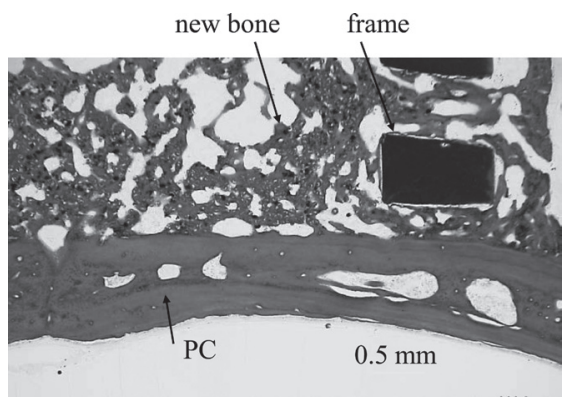

Fig.18 H-E staining of $\mathrm{CO}_{3}$ apatite-collagen composite with rh-BMP2 after 1 month implantation into periosteum cranii $(\mathrm{PC})$ of rat.

成長因子 growth factor, そしてスカフォールド scaffold が重要で ある。従って, スカフォールドとしての生体材料の研究には, 組 織工学との連携がきわめて重要である。高齢化社会を迎え, 歯槽 骨や歯周組織の再建・再生に生体材料への期待が高まっている。 


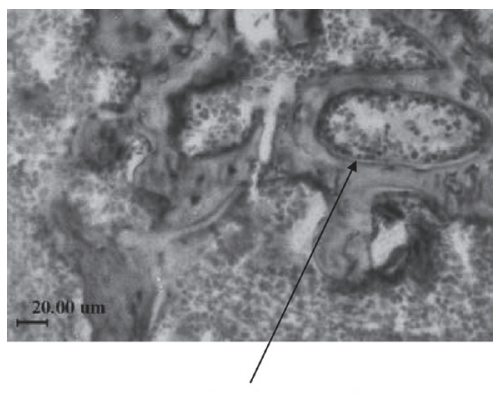

Angiogenesis (factor VIII)

Fig.19 Immunological staining of $\mathrm{CO}_{3}$ apatite-collagen sponge chemically modified with angiogenesis factor, SVVYGLR after 1 wk implantation into rat tibia. S: Serine, V: Valine, Y: Tyrosine, G: Glycine,

L: Leucine, R: Arginine

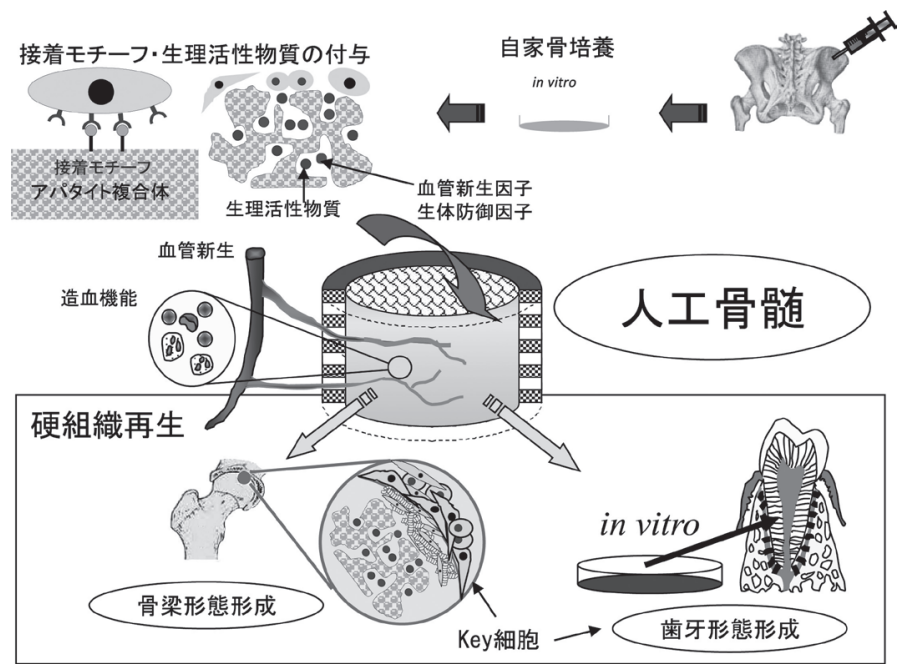

Fig.20 Creation concept of highly functional $\mathrm{CO}_{3}$ apatite-collagen composite.

セラミックスと骨の再生を目的とした組織工学的材料との連携・ 融合と従来概念からのブレークスルーが重要となろう。

\section{References} 期待されている。例えば，上述したように骨アパタイトに類似し た結晶性と組成を有する炭酸アパタイトの合成を行い, 得られた 粉末結晶試料をコラーゲン溶液と混合し, 凍結乾燥するとスポン ジ状スカフォールドができる。また, 高強度でポーラスなアパタ イト円筒状フレームを作成し, スポンジとハイブリッド化すると, 生体骨の緻密骨と海綿骨に類似した構造をもつ人工骨ができあが る。ここ一血管新生因子や骨増殖因子のようなサイトカインを導 入することにより, 生体模倣の人工骨の創製も可能となる。さら に人工骨髄といったような, 造血機能をも備えた硬組織生体材料 の開発や，発生学的発想を取り入れた歯・骨の形態形成 (ものづ くりから形づくり)の研究が期待される (Fig. 20) ${ }^{23)}$ 。最近の ES 細胞や iPS 細胞を用いた再生医療研究の発展には目を見張るもの があるが，ここでも組織や臟器を形作る足場としての生体材料の 役割は欠かせない。やがて, iPS 細胞培養の技術により自分自身 の細胞を培養・初期化することにより, 老化した各組織や臟器に 替わる新鮮なパーツをつくり出せる日が来るかも知れない。 ただ, 現在の代謝性硬組織生体材料では, 解決しきれていない課 題が残っている, それは, 歯科領域, 整形外科領域を問わず, 大 きな欠損部位や大きな力学的応力のかかる部位の治療である。特 に, 歯冠修復としての歯科補綴材料は, 歯質エナメル質が代謝性 を有しないだけに, 今後も歯科領域で重要な人工材料であり, 材 料学的に見て益々注目されていくものと思われる。また, 従来の 人工歯根の形態と機能を如何に天然歯に近づけるかも, 今後に残 された課題である。この点に関して, 高強度の金属や勒性の高い
1) J.B. Parks: Biomaterials. An introduction, (Plenum Press, New York, 1980).

2) M. Okazaki: Chemistry of Apatites, (Tokai University Publishing, Tokyo, 1992).

3) M. Okazaki and K. Yamashita Eds.: Ceramic Biomaterials, (Corona Publishing, Tokyo, 2009).

4) Y. Ikada Ed.: Introduction to Biomaterials, (Gakkai Publishing Center, Tokyo, 1993).

5) S. Suga, S. Taguma and T. Sasaki Eds.: Study Method of Teeth, ( Ishiyaku Publishing, Tokyo, 1973)

6) A.E.W. Miles: Structural and Chemical Organization of Teeth, Vol. II, (New York: Academic Press, 1967).

7) K. Matsuda, et al. Translated: View of Medical Biology, (Maruzen, Tokyo, 1986).

8) B. Albert, D. Bray, J. Lewis, M. Raff, K. Roberts and J.D. Watson: Molecular Biology of the Cell, $3^{\text {rd }}$ Ed. (Garland Publishing, New York, 1994).

9) M.I. Kay, R.A. Young, A.S. Posner: Nature, 204 (1964), 1050-1052

10) R.A. Young: Trans New York Acad Sci, 29 (1967), 949-959.

11) J.R. Van Wazer: Phosphorus and Its Compounds, (Interscience, New York, 1958)

12) St.N. Szeged and P.T.Manchester: Z Kristallogr, 75 (1930), 387-398.

13) R.Z. LeGeros: Science, 155 (1967), 1409-1411.

14) M. Okazaki, Y. Moriwaki, T. Aoba, Y. Doi and J. Takahashi: Caries Res, 15 (1981), 477-483.

15) A. Matsuura, T. Kubo, K. Doi, K. Hayashi, K. Morita, R. Yokota, H. Hayashi, I. Hirata, M. Okazaki and Y. Akagawa: Dent Mater J, 28 (2009), 234-242.

16) M. Okazaki, H. Ohmae and T. Hino: Biomaterials, 10 (1989), 564-568.

17) M. Okazaki, H. Ohmae, J. Takahashi, H. Kimura and M. Sakuda: Biomaterials, 11 (1990), 568-572.

18) M. Itoh, A. Shimazu, I. Hirata, Y. Yoshida, H. Shintani and M. Okazaki: Biomaterials, 25 (2004), 2577-2583.

19) Y. Tieliewuhan, I. Hirata, A. Sasaki, H. Minagi and M. Okazaki: Dent Mater J, 23 (2004), 258-264.

20) Y. Yamasaki, Y. Yoshida, M. Okazaki, A. Shimazu, T. Kubo, Y. Akagawa, T. Uchida: Biomaterials, 24 (2003), 4913-4920.

21) I. Hirata, Y. Nomura, M. Ito, A. Shimazu and M. Okazaki: Artif Organs, 10 (2007), 212-217.

22) Y. Hamada, H. Egusa, Y. Kaneda, I. Hirata, N. Kawaguchi, T. Hirao, T. Matsumoto, M. Yao, K. Daito, M. Suzuki, H. Yatani, M. Daito, M. Okazaki and N. Matsuura: Dent Mater J, 26 (2007), 487-492.

23) M. Okazaki: Biomaterials (In Japanese), 26 (2008), 101-110. 